Sensoriamento remoto como instrumento de controle e proteção ambiental: análise da cobertura vegetal remanescente na bacia do rio Araguaia Luciane Martins de Araújo Mascarenhas, Manuel Eduardo Ferreira, Laerte Guimarães Ferreira

\title{
SENSORIAMENTO REMOTO COMO INSTRUMENTO DE CONTROLE E PROTEÇÃO AMBIENTAL: ANÁLISE DA COBERTURA VEGETAL REMANESCENTE NA BACIA DO RIO ARAGUAIA
}

\author{
Remote Sensing as a Law Enforcement and Environmental Protection Tool: Remnant \\ Vegetation Analysis in the Araguaia River Basin
}

Luciane Martins de Araújo Mascarenhas

Doutoranda em Ciências Ambientais pela Universidade Federal de Goiás

Goiania/GO - Brasil

lucianemartins@brturbo.com.br

Manuel Eduardo Ferreira

Doutorando em Ciências Ambientais pela Universidade Federal de Goiás

Goiania/GO - Brasil

manuel@iesa.ufg.br

Dr. Laerte Guimarães Ferreira

Professor Adjunto da Universidade Federal de Goiás

Goiania/GO - Brasil

laerte@pq.cnpq.br

Artigo recebido para publicação em 09/06/2008 e aceito para publicação em 23/12/2008

RESUMO: $\quad$ A legislação brasileira sobre as Áreas de Preservação Permanente (APP) e os Recursos Hídricos foi analisada associando os dispositivos legais com a cobertura vegetal remanescente na Bacia do Rio Araguaia. Com base no indice de vegetação por diferença normalizada (NDVI) aplicado a um mosaico de 21 cenas do satélite CBERS II (julho-agosto de 2006), foi detectada uma conversão da ordem de $61 \%$ da cobertura vegetal na bacia como um todo, e de aproximadamente $45 \%$ ao longo dos ambientes ripários. Estes dados corroboram a necessidade de um maior empenho na observância legal por parte dos proprietários rurais, bem como a adoção de céleres decisões por parte do Poder Público, com vistas a reduzir ou controlar a ocorrência de novos desmatamentos nessa e em outras regiões do bioma Cerrado.

Palavras-chave: Sensoriamento remoto. Bioma Cerrado. Áreas de Preservação Permanente. Índice de vegetação. Rio Araguaia.

ABSTRACT: In this study, the Brazilian legislation regarding the permanent protected areas (APP) and the water resources was investigated by simultaneously analyzing the available legal instruments and the current vegetation cover in the Araguaia River basin. Through the normalized difference vegetation index (NDVI), applied to a CBERS II mosaic, comprising 21 satellite imagery (July-August, 2006), we detected a land conversion of about $61 \%$ in the study area as a whole, and of about $45 \%$ along the riparian zone. These figures corroborate the need of a stronger compliance, by the landowners, to the Forest 
Sensoriamento remoto como instrumento de controle e proteção ambiental:

análise da cobertura vegetal remanescente na bacia do rio Araguaia

Luciane Martins de Araújo Mascarenhas, Manuel Eduardo Ferreira, Laerte Guimarães Ferreira

Code, and fast pace decisions by local and federal authorities, so that new deforestations, in the Araguaia basin and other important areas in the Cerrado biome, can be either prevented or reduced.

Keywords: Remote sensing. Cerrado biome. Permanent Protected Areas. Vegetation index. Araguaia River.

\section{Introdução}

A legislação ambiental brasileira apresenta vários institutos que visam à proteção do meio ambiente. Essa preocupação encontra-se presente na Constituição Federal, em seu artigo 225, que garante a todos o direito ao meio ambiente ecologicamente equilibrado. Um importante instrumento de proteção do meio ambiente está disciplinado no artigo $2^{\circ}$ do Código Florestal brasileiro, Lei 4.771/1965, que inclui as Áreas de Preservação Permanente (APP). Essas áreas têm como função precípua a preservação dos recursos hídricos e a biodiversidade. Este trabalho irá discorrer, principalmente, sobre as áreas de preservação permanente no entorno dos cursos d'água.

Os cursos d'água têm uma importância fundamental na história, pois serviram como via para a conquista de novas fronteiras e são recursos fundamentais para a sobrevivência humana, o que justifica a preferência dessas áreas para o cultivo agrícola, criação de animais e para o crescimento dos aglomerados urbanos. Infelizmente, o ser humano não tem dado o valor e a prioridade necessária a este recurso natural, bastando observar que grande parte dos rios é utilizada para o descarte dos efluentes gerados nas cidades e pelas indústrias.

A água é essencial às funções vitais e esse recurso, existente na biosfera na forma líquida, cobre certa de $3 / 4$ do globo terrestre, sendo que mais de $97 \%$ estão nos oceanos e menos de $3 \%$ são de água doce. Desse percentual, 77\% estão congeladas nos círculos polares, $22 \%$ é composta de água subterrânea, e apenas $1 \%$ está disponível como água não salgada superficial, apropriada para o consumo humano (SILVA, 2005).
O maior consumo da água se dá nas atividades agrícolas, seguida pelas atividades industriais. Estimase que a agricultura consuma cerca de $73 \%$ da água existente no mundo, sendo grande parte dela desperdiçada, uma vez que quase $60 \%$ se perde antes de atingir a planta (SILVA, 2005). Nesse sentido, é bom destacar que as APPs em torno dos cursos d'água exercem importância fundamental para os recursos hídricos, servindo de filtro para evitar a sua contaminação por fertilizantes e agrotóxicos, para a retenção hídrica no solo e subsolo, para a contenção dos processos erosivos e assoreamento dos rios, bem como favorecendo a manutenção da biodiversidade (RESENDE, 1996).

Um dos biomas que mais tem sofrido pela falta de observância da legislação ambiental é o Cerrado, que corre sério risco de extinção. De fato, o Cerrado é considerado pela Conservation International como uma das 34 áreas prioritárias para conservação da biodiversidade mundial (hotspots), com estimativa de perda anual de cobertura vegetal nativa de $1,5 \%$, ou seja, aproximadamente três milhões de hectares/ano, em virtude dos altos índices de desmatamento (MACHADO et al., 2004).

Em particular, o segmento de Cerrado correspondente à Bacia do Alto Araguaia vem sofrendo forte desmatamento desde o início da década de 1970, fomentado principalmente pelo Programa de Desenvolvimento do Cerrado - POLOCENTRO, implantado em 1975. O desmatamento indiscriminado e intensivo, aliado a um novo sistema produtivo para a época (agropecuária), geraram como impactos o comprometimento da biodiversidade, $\mathrm{o}$ assoreamento e surgimento de processos erosivos e a contaminação dos solos e águas por fertilizantes e agrotóxicos (CASTRO, 2005). 
Estimativas quanto ao percentual de áreas convertidas do Cerrado, o qual responde por cerca de um quarto do total de grãos produzidos no Brasil e, aproximadamente, 40 milhões de cabeças de gado (SANO et al., 2002), variam de 39,5\% (SANO et al., 2008) a 54,9\% (MACHADO et al., 2004). Isso demonstra a necessidade de preservação, não só em função de sua rica biodiversidade, como também dos recursos hídricos nele existentes, como é o caso do Rio Araguaia, localizado na divisa dos Estados de Goiás e Mato Grosso.

Frente a essa situação, o sensoriamento remoto tem se mostrado um instrumento de grande utilidade para o monitoramento de grandes áreas, a fim de verificar a observância à legislação ambiental. As imagens geradas por meio de satélites estão cada vez mais em voga e se popularizam a cada dia, mormente após a divulgação gratuita pela internet, por meio de iniciativas como o Google Earth, já acessado por milhões de pessoas no mundo todo (FERREIRA et al., 2008).

O estudo ora realizado visa fazer a correlação entre o instituto jurídico das Áreas de Preservação Permanente e um dos mecanismos tecnológicos que tem auxiliado na proteção do meio ambiente, qual seja, o sensoriamento remoto. Especificamente, busca avaliar, por meio da utilização de imagens do satélite sino-brasileiro CBERS II, o "passivo ambiental" existente em parte da Bacia do Rio Araguaia, em particular, nos seus ambientes ripários/Áreas de Preservação Permanente.

\section{Conhecendo melhor o bioma Cerrado}

O bioma Cerrado, o segundo maior bioma brasileiro, ocupa uma extensão de aproximadamente 2.045.064,8 $\mathrm{Km}^{2}$, englobando, além da Região Centro-Oeste, parte das regiões Sudeste, Nordeste e Norte do Brasil. Em suas diversas configurações, o Cerrado encontra-se presente, de forma contínua, em dez estados brasileiros, bem como no Distrito Federal, cobrindo cerca de $24 \%$ do território nacional (IBGE, 2004).
É importante ressaltar que seis das oito mais importantes bacias hidrográficas do Brasil têm suas origens na região do Cerrado (WATZEN, 2006). Dentre estas, destacam-se a Bacia Amazônica (com origem na Bacia Araguaia-Tocantins) e as bacias do Paraná-Paraguai e Rio São Francisco.

A vegetação do Cerrado está adaptada ao longo período de estiagem. O clima característico desse bioma possui duas estações bem definidas, uma seca e outra chuvosa. As chuvas concentram-se principalmente entre os meses de outubro a abril, prevalecendo o clima seco nos demais meses (ASSAD, 1994).

De acordo com EINTEN (1972), a caracterização das formas fisionômicas do Cerrado depende de três aspectos: 1) a fertilidade e o correlacionado teor de alumínio (mais alumínio, menos fertilidade); 2) a profundidade do solo e 3 ) o grau e duração de saturação da camada superficial ou subsuperficial do solo. Estas fisionomias naturais são modificadas por fogo periódico provocado pelo homem ou por causas naturais, como raios. O fogo torna menos densa e baixa a camada lenhosa (caule grosso). Segundo esse autor, as fisionomias do Cerrado são classificadas como:

- Cerradão: composto de árvores de grande porte, com estrato arbóreo geralmente entre 10 e 12 metros, com cobertura fechada ou semi-aberta;

- Cerrado ou Cerrado em sentido estrito, apresentando 2 estratos: um arborescente, que pode atingir até 6 metros, e um estrato baixo bem desenvolvido, formado por gramíneas, subarbustos e algumas ervas;

- Campo cerrado: forma mais pobre em nível estrutural e florístico, onde os indivíduos do estrato arborescente são mais esparsos, menores e retorcidos, com estrato baixo mais destacado;

- Campo sujo: constituído por um estrato herbáceo bem desenvolvido, composto principalmente de gramíneas, onde se distribuem, de maneira mais esparsa, alguns arbustos e pequenas árvores;

- Campo limpo: composto por um único estrato, constituído principalmente por gramíneas. 
Sensoriamento remoto como instrumento de controle e proteção ambiental:

análise da cobertura vegetal remanescente na bacia do rio Araguaia

Luciane Martins de Araújo Mascarenhas, Manuel Eduardo Ferreira, Laerte Guimarães Ferreira

Pelo seu aspecto fisionômico, o Cerrado é considerado um bioma feio e sem importância, motivo pelo qual cedeu espaço a grandes monoculturas e a pecuária, correndo sérios riscos de extinção. Esse descaso é sentido também no aspecto da proteção legal, visto que a Lei Maior, ou seja, a Constituição Federal, ao garantir a proteção do meio ambiente em seu artigo $225, \S 4^{\circ}$, deu destaque especial a alguns biomas brasileiros como a Floresta Amazônica, a Mata Atlântica, a Serra do Mar, o Pantanal MatoGrossense e a Zona Costeira, os quais, pelo seu relevante valor e necessidade de preservação, são considerados "patrimônio nacional".

Em face disso, há 12 anos tramita no Congresso Nacional uma emenda constitucional visando incluir o Cerrado e a Caatinga nordestina como patrimônios nacionais, por meio da Proposta de Emenda à Constituição - PEC 115/1995, de autoria da deputada federal da bancada do Estado de Goiás, Neyde Aparecida (CÂMARA DOS DEPUTADOS, 2008a).

Por desconhecer a rica biodiversidade do Cerrado, esse bioma passou a ser a principal alternativa para a expansão da fronteira agropecuária no Brasil, visto que, além de ser considerado (erroneamente) como um ecossistema de menor complexidade que o da Floresta Amazônica, ainda conta com outros atrativos, tais como a facilidade de mecanização - em função de um relevo predominantemente plano -, a proximidade de mercados consumidores, a existência de ampla malha viária, o baixo valor das terras, e a possibilidade de irrigação pela disponibilidade hídrica (RESENDE, 1996).

Há também uma grande preocupação com os solos do Cerrado, visto que, para obtenção de safras cada vez mais rentáveis há um grande investimento em corretivos e adubos. A utilização de produtos químicos afeta diretamente a camada superficial do solo, favorecendo ao processo de eutrofização. Por outro lado, a melhoria das condições químicas ocorre apenas superficialmente, não atingindo as camadas mais profundas do solo (RESENDE, 1996).

\section{As Áreas de Preservação Permanente e os recursos hídricos na legislação brasileira}

Os vários tipos de vegetação, bem como os recursos hídricos, são elementos que integram o meio ambiente, que é objeto de tutela pela Constituição Federal brasileira, em seu artigo 225, que garante a todos o meio ambiente ecologicamente equilibrado, essencial à sadia qualidade de vida, impondo-se ao Poder Público e à coletividade o dever de defendê-lo e preservá-lo para as gerações atuais e futuras.

Ao Poder Público, além do disciplinamento legal, incumbe promover a gestão dos recursos naturais e apresentar mecanismos de prevenção, fiscalização e controle. À coletividade também cumpre o dever da defesa e da preservação.

\subsection{O Código Florestal Brasileiro}

O Código Florestal, em sua primeira versão, foi editado com o objetivo de conter o avanço do desmatamento no Brasil. É considerado um poderoso instrumento legal na preservação da cobertura vegetal brasileira (MILARÉ, 2007).

Merece destaque no Código Florestal, o instituto da Reserva Legal, que corresponde a uma área localizada no interior de uma propriedade rural, excluída a área de preservação permanente, necessária ao uso sustentável dos recursos naturais, à conservação e reabilitação dos processos ecológicos, à conservação da biodiversidade e ao abrigo da fauna e flora nativas (art. $1^{\circ}, \S 2^{\circ}$, inciso III, Código Florestal).

Para as áreas localizadas na Amazônia Legal em área de floresta, a Reserva Legal corresponde a 80\%. Já em áreas de Cerrado, dentro da Amazônia Legal, esse percentual cai para 35\%. Para os demais biomas brasileiros a Reserva Legal equivale a $20 \%$ da área da propriedade (art. 16), como é o caso da área core do Cerrado.

O conceito de Reserva Legal foi introduzido pela Medida Provisória (MP) 2.166/2001, que teve 
sua origem na MP 1.511/1996, e que aumentou o percentual de reserva legal para as áreas de florestas da Amazônia legal de $50 \%$ para $80 \%$ com o fito de diminuir o desmatamento na Amazônia, o qual já vinha sendo divulgado pelo Instituto Nacional de Pesquisas Espaciais - INPE (MILARÉ, 2007).

Novas e preocupantes alterações ao Código Florestal são objetos de diversos Projetos de Lei (PL) como, por exemplo, o PL 6424/2005, 6840/2006 e 1207/2007, o qual defende a redução da área de reserva na Amazônia Legal de $80 \%$ para até 50\% nos imóveis rurais. Além disso, possibilita a redução das áreas de reserva para até 30\% do imóvel rural ou posse no caso de uso para plantio de espécies florestais nativas ou exóticas e, ainda o replantio das áreas desmatadas com espécies exóticas. Esses projetos também preveem que áreas já destruídas e destinadas à agricultura ou pecuária possam continuar a ser exploradas, desde que não haja novos desmatamentos. Pretende-se, ainda, a alteração da definição de áreas de preservação permanente, diminuindo sua área de abrangência no caso das áreas situadas na Mata Atlântica (CÂMARA DOS DEPUTADOS, 2008b).

Nota-se portanto, que várias conquistas da legislação ambiental correm sério risco de sofrerem profundas e desastrosas alterações, o que coloca em risco a manutenção da biodiversidade.

\subsection{As áreas de Preservação Permanente}

$\mathrm{O}$ artigo primeiro, parágrafo segundo, inciso II, do Código Florestal estabelece como área de preservação permanente aquela que é coberta ou não por vegetação nativa, com a função ambiental de preservar os recursos hídricos, a paisagem, a estabilidade geológica, a biodiversidade, o fluxo gênico de fauna e flora, proteger o solo e assegurar o bem estar das populações humanas.

Observa-se que a previsão legal contempla, de forma acertada, a manutenção da vegetação, que contribui com o equilíbrio dos demais recursos naturais envolvidos. Trata-se da visão sistêmica de meio ambiente, onde cada elemento mantém-se distinto um do outro, porém possui indissociáveis interações e relações mútuas (MORIN, 2002). A quebra desse equilíbrio produz efeito em todos esses elementos, inclusive para o próprio ser humano. No caso em estudo, a vegetação ripária constitui um importante elo no funcionamento dos sistemas ambientais.

As áreas de preservação permanente se dividem em legais e administrativas. As legais são aquelas estabelecidas no artigo $2^{\circ}$ do Código Florestal e que serão objetos de análise neste trabalho. As administrativas, por sua vez, são aquelas cuja previsão encontra-se no artigo $3^{\circ}$, ou seja, aquelas declaradas por ato do Poder Público.

$\mathrm{O}$ artigo $2^{\circ}$ do Código Florestal, alíneas "a", "b" e "c", possui como objetivo principal a proteção dos recursos hídricos e, ainda do solo e vegetação que circunda esses cursos d'água. Essas áreas são conhecidas como mata ciliar, mata de galeria, mata de várzea, ou vegetação ripária em geral, que são formações vegetais localizadas às margens dos rios, córregos e nascentes.

$\mathrm{O}$ artigo $2^{\circ}$ possui ainda os dispositivos constantes nas alíneas "d" até "h", cujo objetivo primordial é a proteção do solo, tais como, topos de morros, encostas, restingas, bordas de tabuleiro ou chapadas. Esclarece-se ainda que, o parágrafo único do artigo $2^{\circ}$ estabelece que no caso de áreas urbanas, deve-se observar o disposto nos planos diretores e leis de uso do solo relativo às áreas de proteção permanente.

Em relação às APPs em torno dos cursos d'água, o artigo $2^{\circ}$ do Código Florestal considera como área de preservação permanente as florestas, e demais formas de vegetação natural, situadas ao longo dos rios ou de qualquer curso d'água com largura mínima: de 30 metros para os cursos d'água com menos de 10 metros de largura; de 50 metros para os cursos d'água que tenham de 10 a 50 metros de largura; de 100 metros para os cursos d'água que tenham de 50 a 200 metros de largura; de 200 metros para os cursos d'água que tenham de 200 a 600 metros 
Sensoriamento remoto como instrumento de controle e proteção ambiental:

análise da cobertura vegetal remanescente na bacia do rio Araguaia

Luciane Martins de Araújo Mascarenhas, Manuel Eduardo Ferreira, Laerte Guimarães Ferreira

de largura; e de 500 metros para os cursos d'água que tenham largura superior a 600 metros. Constituem ainda áreas de preservação permanente o entorno de lagoas, lagos e nascentes (art. 20, "b" e "c").

Reforçando a necessidade de proteção das áreas de preservação permanente, sobretudo das nascentes dos rios, vale ressaltar que a Lei $\mathrm{n}^{0} 7.754 /$ 1989 estabelece, em seu artigo $2^{\circ}$, medidas para proteção das florestas existentes nesses locais, através da constituição de uma área em forma de paralelograma, denominada "Paralelograma de Cobertura Florestal", na qual são vedadas a derrubada de árvores e qualquer forma de desmatamento. Prevê ainda, em seu parágrafo primeiro, que na hipótese em que, antes da vigência da Lei, tenha havido derrubada de árvores e desmatamento na área integrada no Paralelograma de Cobertura Florestal, deverá ser imediatamente efetuado o reflorestamento, com espécies vegetais nativas da região. As dimensões do paralelograma devem ser fixadas por regulamento.

A Medida Provisória 2.166/2001 alterou algumas disposições do Código Florestal, em que se destaca a mudança ocorrida no artigo $4^{\circ}$, o qual passou a permitir a supressão total ou parcial das áreas de preservação permanente mediante autorização do órgão ambiental competente, em caso de utilidade pública ou de interesse social, devidamente caracterizados e motivados em procedimento administrativo próprio, quando inexistir alternativa técnica e locacional ao empreendimento proposto. Pelo disposto no parágrafo quinto do artigo em questão, é autorizada inclusive a supressão da vegetação nativa protetora de nascentes, ou de dunas e mangues, de que tratam, respectivamente, as alíneas "c" e "f" do art. 2º deste Código; Porém, somente nos casos de utilidade pública, cuja definição encontrase no artigo $1^{\circ}, \S 2^{\circ}$, incisos IV e V do Código Florestal.

Essas alterações foram objetos de grande polêmica, o que culminou com o ajuizamento da Ação Direta de Inconstitucionalidade (ADIn) $\mathrm{n}^{\circ}$ 3.540, impugnando as mudanças trazidas pela MP. Em que pese no primeiro momento haver sido concedida decisão liminar suspendendo a eficácia das alterações introduzidas ao artigo $4^{\circ}$ do Código Florestal, tal decisão não foi referendada pelo Pleno do Supremo Tribunal Federal (STF), o qual restaurou a eficácia e a plenitude do dispositivo legal. A ADIn em comento encontra-se pendente de julgamento do mérito (STF).

A decisão proferida pelo Pleno do STF entendeu que a MP 2.166/2001 trouxe um avanço expressivo na tutela das áreas de preservação permanente. No entanto, o receio é que esse avanço resulte na perda irreparável da biodiversidade, prevalecendo os interesses econômicos e políticos e não traga benefícios à coletividade (MACHADO, 2007).

Com respaldo na decisão do Supremo Tribunal Federal, foi editada a Resolução CONAMA $\mathrm{n}^{\circ} 369 / 2006$, que regulamentou o artigo $4^{\circ}$ introduzido pela MP 2.166/2001, definindo os casos em que o órgão ambiental competente pode autorizar a intervenção ou supressão de vegetação em APPs.

No que se refere ainda ao artigo $4^{\circ}$, vale destacar as disposições do parágrafo sétimo, que estabelece a permissão do acesso de pessoas e animais às áreas de preservação permanente para obtenção de água, desde que não exija a supressão e não comprometa a regeneração e a manutenção da vegetação nativa. Especificamente na área de estudo, como já apontado, a atividade econômica predominante é a agropastoril, com destaque para a criação de gado. Assim, é permitido o acesso de animais para a obtenção de água, desde que não haja comprometimento da área preservada.

Relativamente à tutela penal e administrativa das áreas de preservação permanente, vale destacar que a Lei no 9.605/1998 (Lei de Crimes Ambientais) trata, nos artigos 38 a 53, dos crimes contra a flora. $\mathrm{O}$ referido texto legal considera crime contra a flora a destruição e danificação de floresta considerada de preservação permanente, bem como o corte de árvores nessas áreas, sem a devida permissão da autoridade competente. Também é considerado crime provocar incêndio em mata ou floresta (art. 41), a extração de 
florestas consideradas de preservação permanente, sem prévia autorização (art. 44), impedir ou dificultar a regeneração natural das florestas e demais formas de vegetação (art. 48), dentre outros. Por meio do Decreto 3.179/1999 houve a regulamentação quanto às sanções administrativas em que se refere a Lei $\mathrm{n}^{\circ}$ 9.605/1998.

Há que se destacar, portanto, a possibilidade da pessoa física ou jurídica que incorrer em alguma das condutas tipificadas como crime ou ilícito administrativo vir a sofrer a imputação na esfera penal, tais como: detenção, reclusão, penas restritivas de direitos (como a prestação de serviços à comunidade) e, ainda, sanção na esfera administrativa (advertência, multa, suspensão de atividades, etc.). E mais, pode ser responsabilizado na esfera civil, quando causar danos a terceiros, ou à coletividade, ou ainda ao patrimônio público, podendo ser condenado a pagar indenização em razão do dano causado.

\subsection{O disciplinamento legal sobre os recursos hídricos}

A Lei $n^{\circ}$ 9.433/1997 instituiu a Política Nacional de Recursos Hídricos, trazendo seus fundamentos no artigo $1^{\circ}$, onde consta a água como bem de domínio público, dotado de valor econômico e que a sua gestão deve proporcionar o seu uso múltiplo, dando prioridade ao consumo humano e a dessedentação de animais. Prevê ainda, que a unidade territorial para a implementação da Política Nacional de Recursos Hídricos é a bacia hidrográfica. $\mathrm{O}$ artigo 37 estabelece que a bacia hidrográfica abrange os cursos d'água classificados como principais e tributários. $\mathrm{O}$ artigo $1^{\circ}$, inciso VI traz também, como fundamento dessa política, que sua gestão deve ser descentralizada, com a participação do Poder Público e da sociedade, criando, para tanto, os Comitês de Bacia Hidrográfica, conforme disposto no artigo 37. Os comitês funcionam como órgãos colegiados heterogêneos que têm por finalidade estabelecer as prioridades sobre a gestão, o acompanhamento do plano de recursos hídricos, o consumo, a recuperação e o tratamento da água.
O Comitê de Bacias Hidrográficas, juntamente com o Conselho Nacional de Recursos Hídricos, a Agência Nacional de Águas, os Conselhos de Recursos Hídricos estaduais e do Distrito Federal e os órgãos dos poderes públicos federal, estaduais e municipais relacionados à gestão de águas formam o Sistema Nacional dos Recursos Hídricos, art. 33, órgão responsável pela coordenação da gestão integrada das águas (art. 32).

Essas disposições legais trouxeram um avanço significativo para a gestão das águas, visto que possibilitam a participação das comunidades e demais interessados pelos recursos hídricos, os quais podem expor seus interesses e discutí-los, podendo ainda ter acesso aos estudos técnicos sobre a disponibilidade do recurso hídrico feito pela Agência de Água vinculada ao comitê de bacia (SILVA, 2005).

Relativamente à área objeto de estudo deste artigo, convém destacar que o Rio Araguaia, que se localiza na divisa dos Estados de Goiás e Mato Grosso, é considerado um bem da União, tendo em vista as disposições do artigo 20, inciso III da Constituição Federal, que estabelece como bens da União os rios que banhem mais de um Estado.

A Resolução n ${ }^{\circ}$ 5/2000 do Conselho Nacional de Recursos Hídricos (CNRH) dispôs que se o curso de água principal for de domínio da União, os comitês respectivos serão vinculados àquele conselho. Pela Resolução CNRH n ${ }^{\circ}$ 32/2003 foi instituída a Divisão Hidrográfica Nacional em regiões hidrográficas, que correspondem ao espaço territorial compreendido por uma bacia, grupo de bacias ou sub-bacias hidrográficas. Por meio de seus anexos I e II, ficou estabelecida a área de região hidrográfica do Tocantins-Araguaia.

Destaque-se que a Lei 9.433/1997 teve o cuidado de buscar a ligação dos recursos hídricos com os aspectos sociais, culturais, econômicos (art. $3^{\circ}$, incisos II e IV), bem como com os demais recursos naturais (art. $3^{\circ}$, inciso III) e, ainda, a articulação da gestão dos recursos hídricos com a do uso do solo (art. $3^{\circ}$, inciso V). Esses aspectos são muito 
Sensoriamento remoto como instrumento de controle e proteção ambiental:

análise da cobertura vegetal remanescente na bacia do rio Araguaia

Luciane Martins de Araújo Mascarenhas, Manuel Eduardo Ferreira, Laerte Guimarães Ferreira

importantes, haja vista a estreita ligação entre a vegetação, o solo e os recursos hídricos, levando-se em consideração as atividades humanas desenvolvidas no local (MACHADO, 2007).

Deve-se também ressaltar que o Artigo 49 estabeleceu como infração das normas de utilização dos recursos hídricos superficiais e subterrâneos, dentre outros, derivar, utilizar ou perfurar poços para extração de água sem a devida outorga ou autorização, e implantar empreendimento relacionado à derivação ou utilização de recursos hídricos sem a autorização dos órgãos competentes. Observe-se, ainda, que a Lei de Crimes Ambientais (Lei n ${ }^{\circ}$ 9.605/1998) estabelece como conduta tipificada como crime, em seu artigo $45, \S 2^{\circ}$, inciso III, causar poluição hídrica que torne necessária a interrupção do abastecimento público de água. Da mesma forma, os artigos 270 e 271 do Código Penal tipificam como crime envenenar, corromper ou poluir água potável. Conforme exposto no subitem anterior (3.2), a responsabilidade do infrator não se restringe ao aspecto penal ou administrativo, que pode ser também responsabilizado civilmente pela prática de atos lesivos aos recursos hídricos.

\section{Importância do Sensoriamento Remoto para proteção do meio ambiente}

A degradação do meio ambiente, o uso não sustentável dos recursos naturais e as mudanças climáticas têm sido algumas das preocupações recorrentes de vários cientistas no mundo inteiro (IPCC, 2007a). Os temas acima, de grande abrangência e complexidade, necessitam cada vez mais da adoção de metodologias de monitoramento sistemático e sinóptico. Destaca-se, assim, o sensoriamento remoto como uma importante ferramenta à análise e controle das questões ambientais.

O avanço tecnológico das últimas décadas favoreceu o desenvolvimento de vários satélites de monitoramento terrestre-ambiental, os quais possibilitam, em escala global, regional ou local, a coleta de dados (quantitativos e qualitativos) sobre o grau de degradação ao meio ambiente, incluindo o acompanhamento de biomas ameaçados de extinção, alterações climáticas, níveis de poluição da água e da atmosfera, dentre outras medições possíveis.

Relativamente aos recursos hídricos, essa tecnologia já possibilita o monitoramento do estado de conservação da qualidade da água e dos processos hidrológicos envolvidos, tais como o percurso da água subterrânea e superficial, processos erosivos, além de estimativas de inundação das bacias hidrográficas.

No que concerne à vegetação, o uso de índices de vegetação permite monitorar e quantificar as suas condições biofísicas e distribuição espacial. Ultimamente, a técnica é aplicada, em diversas escalas de análise, para o acompanhamento da cultura agrícola, umidade do solo, ocorrências de estiagens, etc. (LIU, 2006).

O índice de vegetação mais empregado é o NDVI (Normalized Difference Vegetation Index) que, ao realçar o contraste da radiação refletida nos intervalos espectrais do vermelho e infravermelho, que é diretamente proporcional à atividade fotossintética, favorece a identificação das distintas fitofisionomias, bem como os impactos relacionados à atividade antrópica.

Indiretamente, o NDVI é utilizado com bastante êxito, para a caracterização das variabilidades ecológicas e ambientais, tais como a disponibilidade hídrica e de nutrientes no solo, e a presença de pragas agrícolas (LIU, 2006). As imagens NDVI possibilitam também, o monitoramento da dinâmica climática de uma dada região de acordo com o ciclo anual de precipitação e a respectiva resposta da planta aos regimes de seca ou de chuva.

\section{Desenho experimental}

\section{1. Área de estudo}

A área de estudo compreende parte da bacia do Rio Araguaia, que nasce na Serra do Caiapó, na divisa dos Estados de Goiás, Mato Grosso e Mato 
Grosso do Sul (Região Centro-Oeste). De acordo com Latrubesse e Stevaux (2002), este rio é dividido em três segmentos: o Alto Araguaia, que vai desde suas nascentes até a cidade de Registro, percorrendo 450 $\mathrm{Km}$, o Médio Araguaia, que vai da cidade de Registro até Conceição do Araguaia, percorrendo $1.160 \mathrm{Km}$ e, por último, o Baixo Araguaia, que compreende a área desde a cidade de Conceição do Araguaia até a confluência com o Rio Tocantins.

O estudo ora realizado abrange os segmentos do Alto e Médio Araguaia, com área total de 120.333,58 Km² (FIG. 1)

\subsection{Materiais e Métodos}

A avaliação dos desmatamentos na Bacia do Alto e Médio Araguaia teve por base a analise de 21 cenas do Satélite Sino-Brasileiro de Recursos Terrestres (CBERS II - CCD) (BEZERRA et al., 2007), obtidas entre julho e agosto de 2006, e adquiridas gratuitamente junto ao Instituto Nacional de Pesquisas Espaciais (http://www.cbers.inpe.br/).
Estas cenas, georeferenciadas e organizadas em mosaico, foram transformadas em uma imagem índice de vegetação por diferença normalizada (NDVI) (FERREIRA et al., 2003), cujos valores, variando de -1 a 1 , indicam a proporção de vegetação fotossinteticamente ativa. Isto é, quanto mais próximos de 1, mais densa e vigorosa é a cobertura vegetal. Por outro lado, valores tendendo a zero ou negativos indicam a ocorrência de solo, água, ou vegetação em processo de senescência, como é o caso das pastagens que predominam nas áreas antropizadas.

Especificamente, e considerando que a vegetação nativa na área de estudo, em particular ao longo das áreas ripárias, é predominantemente "verde", ao contrário das áreas antropizadas em geral secas durante os meses entre junho e setembro, a imagem NDVI foi "fatiada" em relação ao valor 0.2 . Ou seja, todos os pixels com valores abaixo de 0.2 foram considerados como pertencentes às áreas convertidas, enquanto pixels com valores acima de 0.2 foram considerados como indicativo da presença de vegetação nativa (FIG. 1).

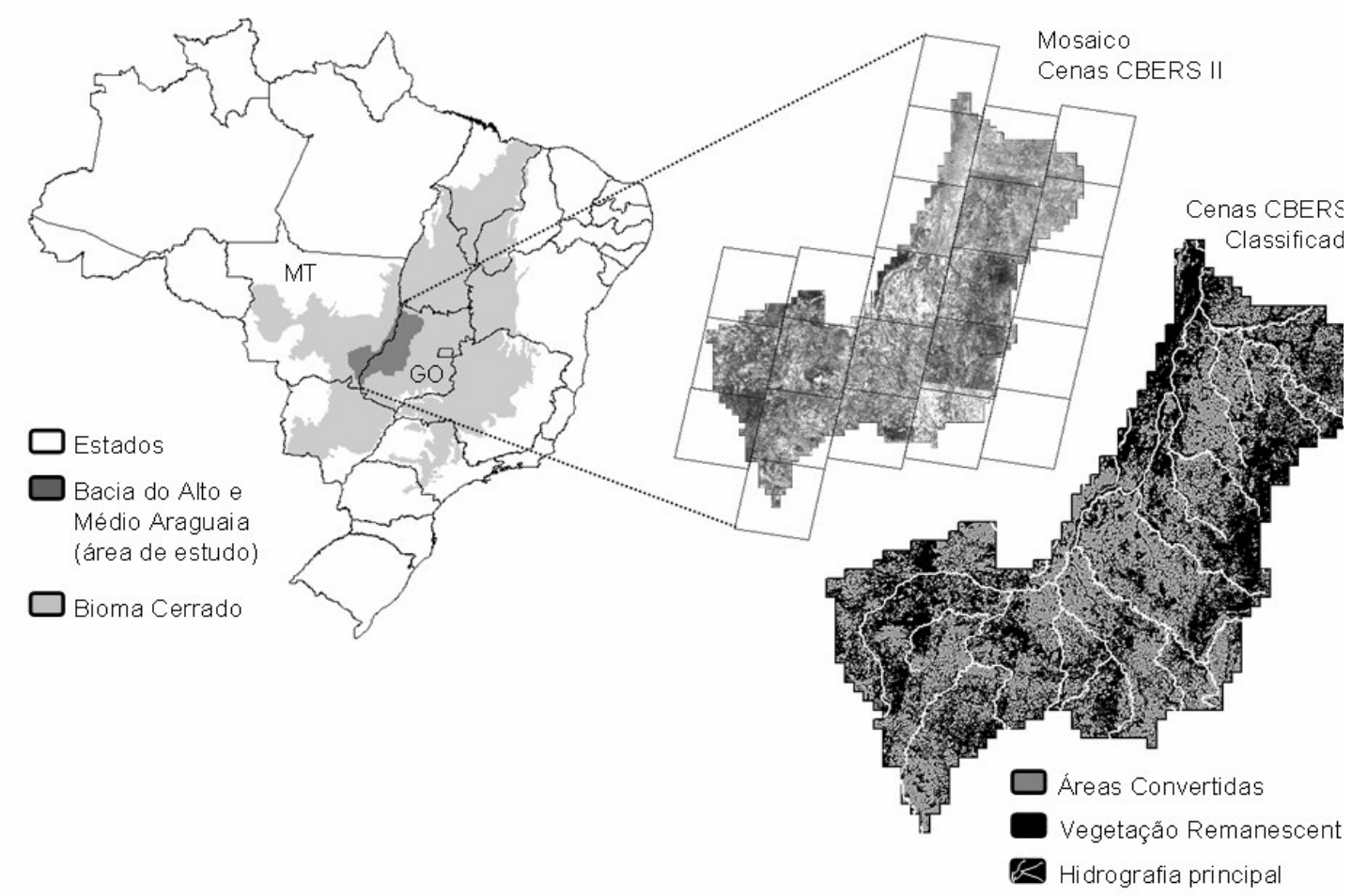

Figura 1. Localização da área de estudo. Em detalhe as imagens obtidas pelo CBERS, com destaque para a vegetação remanescente, áreas convertidas e os cursos d'água. 
Sensoriamento remoto como instrumento de controle e proteção ambiental:

análise da cobertura vegetal remanescente na bacia do rio Araguaia

Luciane Martins de Araújo Mascarenhas, Manuel Eduardo Ferreira, Laerte Guimarães Ferreira

Após os processamentos iniciais, para os quais foram utilizado os softwares ENVI 4.3 e ArcGIS 9.0, a rede de drenagem (IBGE 1:250.000) foi sobreposta à imagem classificada, em relação aos novos ajustes espaciais realizados, com vistas a se obter maior precisão e acuidade entre as bases de dados.

A proporção de áreas remanescentes e convertidas foi estimada para a bacia como um todo, bem como para a zona sob influência ripária. Assim, ao longo de toda linha de drenagem detectável à escala 1:250.000, foi delimitado um buffer de $100 \mathrm{~m}$ de largura. De fato, este buffer corresponde à largura média das Áreas de Proteção Permanente (APPs) no entorno do Rio Araguaia, conforme estabelecido no artigo $2^{\circ}$ do Código Florestal.

\section{Resultados e Discussão}

Por meio da FIG. 2 pode-se constatar que vários cursos d'água que compõem a bacia do Alto e Médio Araguaia, ao contrário do que preconiza o Código Florestal, estão desprovidos de vegetação ripária.

A análise do mosaico CBERS / NDVI indica que uma área de aproximadamente $74.046,99 \mathrm{~km}^{2}$ (i.e. $61,54 \%$ da área total da bacia) já foi convertida, restan- do apenas $46.286,6 \mathrm{Km}^{2}$ de vegetação remanescente.

Em relação à vegetação ripária, delimitada segundo um buffer de $100 \mathrm{~m}$, esta corresponde a uma área total de $14.250,1 \mathrm{Km}^{2}$. Destes, $6.352,56 \mathrm{Km}^{2}$ (44,58\%) foram devastados, infringindo os preceitos estabelecidos pelo Código Florestal no que diz respeito às APPs ao longo dos rios, ou de qualquer corpo d'água presente na área de estudo. Por outro lado, encontra-se preservado o montante de 7.897,54 $\mathrm{Km}^{2}$, o que corresponde a $55,42 \%$ da vegetação ripária / APPs existentes nesta bacia

BONNET et al. (2006), analisando as áreas de preservação permanente e áreas de Reserva Legal no Estado de Goiás e Distrito Federal, constatou que para uma zona ripária média de $100 \mathrm{~m}$ em torno das drenagens detectáveis à escala de 1:250.000, as APPs em Goiás correspondem a 10,9\% do estado, o que, somado às áreas de Reserva Legal (20\%), resulta em um valor de $30,9 \%$ de cobertura vegetal remanescente em atendimento às disposições do Código Florestal. Levando-se em conta que este estudo constatou o equivalente a $38,46 \%$ de remanescentes de Cerrado na área da Bacia do Rio Araguaia, pode-se inferir que a área analisada também se encontra em observância ao Código Florestal.

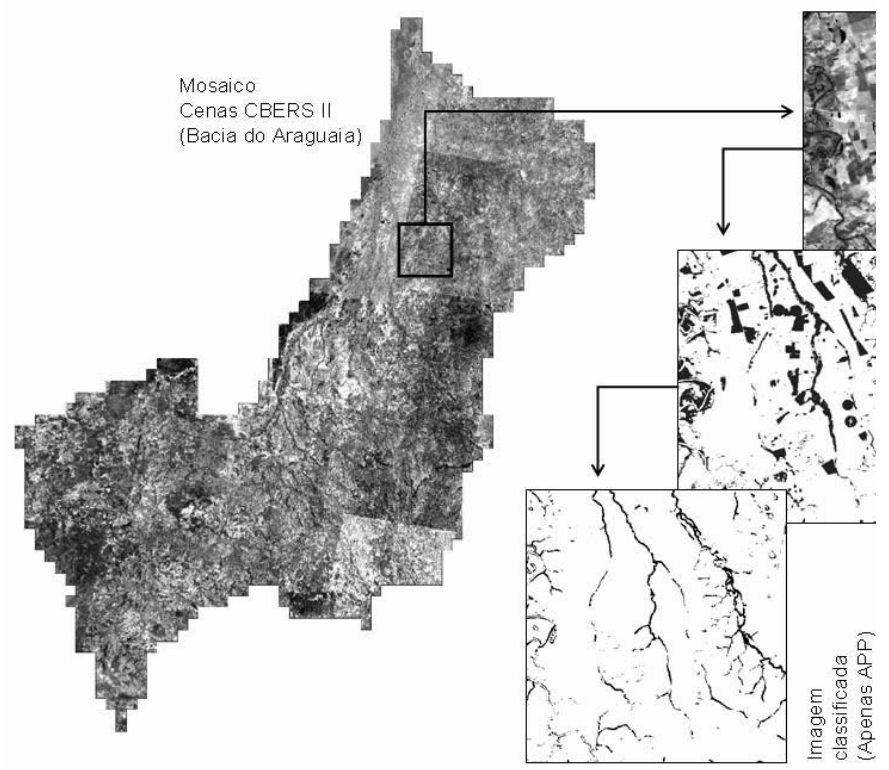

Figura 2. Área de estudo e zoom de parte da Bacia do Rio Araguaia, que evidencia a ausência de vegetação remanescente ao longo de diversos segmentos de drenagem. 
Sob outro prisma, essa conclusão também indica que quase $2 / 3$ da área de estudo já foram convertidos em pastagens ou áreas agrícolas, o que demonstra um alto índice de desmatamento na região.

Em relação à vegetação ripária / APPs analisadas, observa-se que $44,58 \%$ dessas áreas no entorno dos cursos d'água já foram convertidas. Portanto, principalmente em relação ao Rio Araguaia, constata-se o descumprimento dos preceitos estatuídos pelo Código Florestal no que concerne às áreas de preservação permanente. Mesmo sob o argumento de que alguns cursos d'água teriam largura inferior a 100 metros, ainda assim é possível afirmar a existência de um grande passivo ambiental.

A ausência das APPs foi claramente constatada ao longo do curso do Rio Araguaia, principalmente no segmento do Alto e Médio Araguaia. Nesse sentido, vale observar a faixa do segmento médio do rio no Estado do Mato Grosso (figuras 1 e 2), onde a substituição da vegetação nativa das encostas pela agricultura e pecuária não poupou as áreas de preservação permanente.

Na região do médio Araguaia, próximo à cidade de Aruanã (GO), em visita de campo realizada em abril de 2007, pôde-se comprovar in loco a imensa quantidade de terras destinadas à pecuária. Nestas áreas, o desmatamento das matas ciliares, ainda que voltado à facilitar a dessedentação do gado, ocasiona o aumento da área de pastagem em desacordo com as disposições legais relativas às áreas de preservação permanente, em especial a previsão do artigo $4^{\circ}, \S$ $7^{\circ}$, que permite o acesso de animais a essas áreas para obtenção de água, desde que não haja a supressão da vegetação e nem comprometa a sua regeneração e manutenção.

Vários trabalhos científicos têm constatado as conseqüências danosas do desmatamento em descumprimento à legislação ambiental. CASTRO (2005) detectou, por exemplo, a alta concentração de focos erosivos nas nascentes do Rio Araguaia. Em que pese o relevo, o tipo de solo e as chuvas intensas de verão que contribuem para o surgimento desses focos, a ocorrência do processo erosivo, seguido pelo assoreamento dos rios, foi acelerada sobremaneira em razão do uso inadequado dos solos, agricultura intensiva e pelo descumprimento dos ditames do Código Florestal quanto às APPs e Reservas Legais. Com a presença da cobertura vegetal ripária, a infiltração da água no solo ocorre de forma paulatina. Com a ausência desta, a água da chuva passa infiltrar com maior velocidade causando a saturação dos poros do solo, o que acarreta em forte escoamento superficial. A carga de sedimentos levados por este processo acaba por favorecer o aparecimento de erosões (desmoronamento das margens), aumentando a turbidez do rio.

Outros efeitos danosos ao meio ambiente, causados pela intensa ocupação destas áreas, foram constatados pela grande quantidade de sedimentos transportados pelo Rio Araguaia em sua planície aluvial que se localiza em seu segmento médio, visto que esse material provém justamente das formações geológicas aflorantes nas cabeceiras do rio (BAYER, 2002). Ainda que a dinâmica do rio contribua para o desmoronamento das encostas, esse processo está sendo acelerado pelo desmatamento de suas margens, tornando o solo mais suscetível a esse fenômeno, justamente pela ausência de raízes para auxiliar na contenção das margens.

Em projetos como o Brasil das Águas (MOSS, 2007) foram colhidas amostras de água em todo percurso do Rio Araguaia, com a respectiva análise química e biológica. A análise dessas amostras constatou que em vários pontos ao longo do rio há a alteração da composição natural da água em função das ações antrópicas em suas margens (MOSS, 2007). Tais dados corroboram a problemática ambiental abordada neste artigo.

O próprio governo do Estado de Goiás, ao comentar sobre a Bacia do Rio Araguaia, admite que os principais problemas são poluição, assoreamento, desflorestamento de margens e nascentes, e práticas agropecuárias insustentáveis (GOVERNO DO ESTADO DE GOIÁS, 2008). 
Sensoriamento remoto como instrumento de controle e proteção ambiental:

análise da cobertura vegetal remanescente na bacia do rio Araguaia

Luciane Martins de Araújo Mascarenhas, Manuel Eduardo Ferreira, Laerte Guimarães Ferreira

\section{Considerações finais}

Pela análise realizada, pode-se observar que o Brasil conta com um aparato legislativo de grande importância voltado realmente para a conservação dos recursos naturais, a começar pela previsão constitucional trazida no artigo 225 que garante a todos o meio ambiente ecologicamente equilibrado, impondo ao Poder Público o dever de tornar efetiva essa garantia.

Tanto na legislação relativa às APPs (Código Florestal) como na referente aos Recursos Hídricos, há uma preocupação sistêmica abrangendo a questão ambiental como um todo. Com relação aos recursos hídricos (Lei n ${ }^{\circ}$ 9.433/1997), destaca-se a importante inovação representada pelos Comitês de Bacias Hidrográficas, os quais estabelecem a gestão compartilhada desses recursos.

O sensoriamento remoto ocupa espaço ímpar nesse cenário, ao possibilitar um amplo aparato de atuação no que diz respeito ao monitoramento ambiental, imprescindível ao cumprimento dos textos constitucionais tratados neste artigo.

Com relação aos dados obtidos por meio da análise das cenas CBERS II, em especial aos dados extraídos sobre as zonas ripárias ao longo do Rio Araguaia, a situação é de alerta. Nota-se a ocorrência de sérios impactos nas matas ciliares causados pela ação antrópica, sendo necessário maior empenho na observância legal por parte dos proprietários rurais, e adoção de céleres decisões por parte do Poder Público, com vistas a reduzir ou controlar a ocorrência de novos desmatamentos nessa e em outras regiões do bioma Cerrado. É igualmente necessário a fiscalização, o monitoramento e a recuperação das APPs, principalmente onde houve retirada da cobertura vegetal nativa, conscientizando os proprietários sobre o respeito ao Código Florestal, através, quando for o caso, da assinatura de Termo de Ajuste de Conduta - TAC.

Há ainda a possibilidade de se recorrer ao Poder Judiciário em busca da tutela ambiental desrespeitada. Em eventual demanda judicial, as imagens de satélite podem servir como prova da infringência ao dispositivo legal.

Como dever, também da coletividade, na busca por um ambiente ecologicamente sustentável, mostra-se importante a participação da sociedade em busca da proteção do meio ambiente, fiscalizando e denunciando as atividades que não atendem aos dispositivos da lei ambiental ou, por meio do engajamento em projetos de proteção/recuperação de áreas degradadas, dentre outros. Nesse sentido, louváveis se mostram os projetos que têm por objetivo a recomposição das matas ciliares no entorno do Rio Araguaia como o projeto desenvolvido pela Fundação EMAS, que contou com a participação de pesquisadores da Universidade Federal de Goiás (CASTRO, 2005). Outro exemplo é o Programa Nascentes, coordenado pela Polícia Civil do Estado de Goiás (CARVALHO, 2006), o qual tem contribuído para a recomposição da vegetação nativa das áreas de preservação permanente, bem como para a contenção dos processos erosivos nas nascentes do Rio Araguaia. Da mesma forma, a implantação do Comitê Araguaia/Tocantins poderá trazer uma grande contribuição, haja vista a estreita ligação entre os recursos hídricos e a vegetação ripária.

Por fim, em tempos de aquecimento global, mostra-se também importante o cumprimento aos instrumentos legais já existentes, não para alterá-los, mas para que se tornem efetivos. Ao final, irá se constatar que a manutenção das APPs é uma excelente ação contra as conseqüências danosas preconizados pelo Painel Intergovernamental de Mudanças Climáticas à humanidade, pois as árvores são verdadeiros sumidouros de gás carbônico, um dos principais gases causadores do efeito estufa (IPCC, 2007b).

\section{Referências}

ASSAD, E.; CASTRO, R. Chuvas no cerrado: análise e espacialização. Brasília: Embrapa/SPI, 1994.

BAYER, M. Diagnósticos dos processos de erosão/ assoreamento na planície aluvial do Rio Araguaia 
entre Registro do Araguaia (GO) e Cocalinho (MT). Dissertação (Mestrado). Instituto de Estudos SócioAmbientais (IESA). Universidade Federal de Goiás (UFG). 2002, 125 p.

BEZERRA, H.S.; SANO E.E.; FERREIRA, L.G. Desempenho do satélite sino-brasileiro de recursos terrestres CBERS-2 no mapeamento da cobertura da terra no Distrito Federal, Brasil. Revista Brasileira de Geofisica, n. 25, v. 2, p. $171-185,2007$.

BONNET, B.R.P.; FERREIRA, L.G.; LOBO, F.C. Sistema de reserva legal extra-propriedade o bioma Cerrado: Uma análise preliminar no contexto da bacia hidrográfica. Revista Brasileira de Cartografia, n. 58, v. 2, p. 129-137, 2006.

CÂMARA DOS DEPUTADOS. Consulta tramitação das proposições PL 6424/2005. Disponível em: http:/ /www2.camara.gov.br/internet/proposicoes. Acesso em: 28 jan 2008b.

CÂMARA DOS DEPUTADOS. PEC 115/95 Cerrado - patrimônio nacional. Disponível em: http:/ /www2.camara.gov.br/comissoes/temporarias/ especial/pec11595. Acesso em: 28 jan 2008a.

CARVALHO, L.S. Programa de reflorestamento de áreas de preservação permanente para Goiás: Programa nascentes. Goiânia: Diretoria Geral da Polícia Civil do Estado de Goiás, 2006. Disponível em http://www.policiacivil.goias.gov.br/dema/ downloads/pdf/projeto_nascente_55.pdf. Acesso em: 23 jan 2008.

CASTRO, S.S. Erosão hídrica na alta bacia do Rio Araguaia: Distribuição, condicionantes, origem e dinâmica atual. Revista do Departamento de Geografia-USP, v. 17, p. 38-60, 2005.

CONSERVATION INTERNATIONAL. Biodiversity Hotspots. Humam impacts. Disponível em: http:// www.biodiversityhotspots.org/xp/Hotspots/cerrado/ Pages/impacts.aspx. Acesso em: 22 jan 2008.

EITEN, G. The cerrado vegetation of Brazil, 1972.
FERREIRA, L.G.; YOSHIOKA, H.; HUETE, A.; SANO, E.E. Seasonal landscape and spetral vegetation index dynamics in the brasilian Cerrado: An Analysis within the large-scale biosphereatmosphere experiment in Amazônia (LBA). Remote Sensing of Environment, v. 87 p. 534-550, 2003.

; FERREIRA, N.C.; FERREIRA, M.E. Sensoriamento remoto da vegetação: Evolução e estado da arte. Acta Scientiarum, 2008 (no prelo).

GOVERNO DO ESTADO DE GOIÁS. Portal do Agronegócio. Preservação da Bacia do Araguaial Tocantins é discutida em Brasília. Disponível em: http://www.agricultura.go.gov.br/index.php? $\underline{\text { act }=\mathrm{cnt} \& o p t=1,4054}$. Acesso em: 03 jun 2008.

IBGE. Mapa de Biomas do Brasil. Escala 1:5.000.000. 2004. Disponível em: http:// mapas.ibge.gov.br/biomas2/viewer.htm. Acesso em: 22 jan 2008.

IPCC. Painel Intergovernamental sobre mudança do clima. Mudança do clima 2007: Impactos, adaptação e vulnerabilidade. Disponível em: http:// www.mct.gov.br/index.php/content/view/ 50400.html. Acesso em: 03 jun 2008.

IPCC. Painel Intergovernamental sobre mudança do clima. Mudança do clima 2007: Mitigação da mudança do clima. Disponível em: http:// www.mct.gov.br/upd blob/0024/24520.pdf. Acesso em: 30 set $2007 b$.

IRIGARAY. C.T.J.H. O emprego do sensoriamento remoto na proteção das áreas de preservação permanente e reserva legal. Revista de Direitos Difusos, v. 33, p. 37-46, 2005.

LATRUBESSE, E., STEVAUX, J.C. Geomorphology and environmental aspects of Araguaia fluvial basin. Zeitschrift fur Geomorphologie, v. 129, p. 109-127, 2002.

LIU, W.T.H. Aplicações de sensoriamento remoto. Campo Grande: UNIDERP, 2006. 
Sensoriamento remoto como instrumento de controle e proteção ambiental:

análise da cobertura vegetal remanescente na bacia do rio Araguaia

Luciane Martins de Araújo Mascarenhas, Manuel Eduardo Ferreira, Laerte Guimarães Ferreira

MACHADO. P.A.L. Direito Ambiental brasileiro. 15. ed. São Paulo: Malheiros, 2007.

MACHADO. R.B.; NETO, M.B.R.; PEREIRA, P.G.; CALDAS E.F.; GONÇALVES D.A.; SANTOS N.S.; TABOR K.; STEININGER, M. Estimativas de perda do cerrado brasileiro. Conservação Internacional. Brasília, 2004. Disponível em: http:// www.conservation.org.br/arquivos/ RelatDesmatamCerrado.pdf. Acesso em: 03 jun 2008.

MILARÉ, E. Direito do ambiente: A gestão ambiental em foco. Doutrina, prática e jurisprudência, glossário. 5. ed. São Paulo: Revista dos Tribunais, 2007.

MORIN, E. $O$ método 1. A natureza da natureza. Tradução Ilana Heineberg. Porto Alegre: Sulina, 2002.

MOSS. G.; MOSS M. Projeto Brasil das Águas Sete rios: Araguaia. Brasília: 2007, disponível em: http://www.brasildasaguas.com.br/margi/docs/ RIO ARAGUAIA.pdf. Acesso em: 14 dez 2007.

RESENDE, M.; KER FILHO, J.C.; BAHIA FILHO, A.F.C. Desenvolvimento sustentado do cerrado. In: ALVAREZ, V; FONTES L.E.F.; FONTES M.P.F. (Org.). O solo nos grandes domínios do Brasil e o desenvolvimento sustentado. p. 169-197. Viçosa: UFV, 1996.

SANO, E.E.; BARCELOS, A.O.; BEZERRA, H.S. Assessing the spacial distribution of cultivated pastures in the brazilian savanna. Cali: Pasturas tropicales, v. 22, n. 3 (2-15), 2002.

; ROSA, R.; BRITO J.L.; FERREIRA, L.G. Mapeamento semidetalhado (escala de 1:250.000) da cobertura vegetal antrópica do bioma Cerrado. Pesquisa Agropecuária Brasileira, v. 43, n. 1 (153156), 2008.

SILVA, A.L.M. Direito do meio ambiente e dos recursos naturais, v. 2. São Paulo: Revista dos Tribunais, 2005.
STF - SUPREMO TRIBUNAL FEDERAL. Processos. Acompanhamento processual ADIn 3540. Disponivel em: http://www.stf.gov.br/portal/jurisprudencia/ listarJurisprudencia.asp?s1=3540.NUME.\&base=base Monocraticas. Acesso em: 04 jun 2008.

WANTZEN, K.M.; SIQUEIRA, A.; NUNES, C.C.; SA, M.F.P. Stream-valley systems of the brasilian cerrado: impact assessment and conservation scheme. Aquatic Conservation: Marine and Freswater Ecosystems, v. 16, n. 7 (713-732), 2006.

Sociedade \& Natureza, Uberlândia, 21 (1): 5-18, ABR. 2009 